\title{
Exploration and Practice of Cultivating Applied Talents in Colleges against the Background of Education Innovation and Entrepreneurship
}

\author{
YI Hai-sheng \\ Department of student affairs \\ Wuhan polytechnic \\ Wuhan 430074, China \\ 538357318@qq.com
}

\begin{abstract}
Cultivating the innovative spirit and entrepreneurial ability of application-oriented talents is an important embodiment of implementing and cultivating highquality application-oriented talents. Therefore, college teachers should actively study the training mode of college applicationoriented talents against the background of innovation and entrepreneurship, and take into account the basic principles and ideas of cultivating innovation-oriented talents, so that the training mode of application-oriented talents can be truly realized.
\end{abstract}

Keywords-innovation and entrepreneurship education; applied talents; higher education; talent training model

\section{THE NECESSITY OF THE RESEARCH ON THE TRAINING MODE OF APPLIED TALENTS}

At present, Chinese universities are facing the transition from scale expansion to connotation development, which has received unprecedented attention. Against the background of education, China will need a large number of crossover, compound and innovative engineers more than ever before. Therefore, only under the guidance of education concept of innovation and entrepreneurship, can the application-oriented personnel training model constructed conform to the development rules of education itself.

\section{THE BASIC PRINCIPLE OF TRAINING MODE DESIGN FOR INNOVATIVE AND ENTREPRENEURIAL TALENTS}

China's colleges and universities are affected by many factors such as geographical and economic environment. In addition, the independence and professionalism of applicationoriented personnel training often require the design of a personnel training mode with its own training characteristics. Therefore, when carrying out the design of application-oriented personnel training model, Chinese universities should first adhere to the basic principle of "facing all, teaching by classification, combining with specialty, and strengthening practice". Education concept of innovation and entrepreneurship is adopted throughout the whole process of application-oriented talents training, and various links of application-oriented talents training are integrated organically to effectively integrate various training approaches of innovation and entrepreneurship course construction, innovation and entrepreneurship competition, professional training, social enterprise practice and provincial and municipal national competitions. Secondly, it is necessary to break down the "conceptual barrier" of innovation and entrepreneurship education, and improve the teaching target of education which lags behind the development status of innovation and entrepreneurship education. It is necessary to make overall planning for many links of the talent training model in the school. Finally, in order to realize the in-depth development of innovation and entrepreneurship education, it is necessary to step out of the initial stage of "surface education", comprehensively promote the teaching reform of education in universities, and establish the education system mechanism of innovation and entrepreneurship. In this process, it is necessary to promote the communication and connection between universities and governments and enterprises, and explore a new mechanism for collaborative education between universities, enterprises, places, institutions and international cooperation. We will actively attract social resources and foreign investment in high-quality education resources, and comprehensively push forward the in-depth reform of education training for innovation and entrepreneurship of engineering and technology talents.

\section{THE PRACTICE OF THE TRAINING MODE DESIGN OF INNOVATIVE AND ENTREPRENEURIAL TALENTS}

\section{A. To establish a practice-oriented personnel training system}

In view of the different objectives of personnel training in different types of institutions of higher learning, it is necessary for comprehensive colleges and universities to deeply study the local economic development, economic industrial structure and the types of talents needed for local economic and social development in order to realize the fundamental task of cultivating application-oriented talents with innovation and entrepreneurship ability. In order to study the advantages and characteristics of the development of peripheral higher education, it is necessary to seek development with its characteristics, strengthen its strength with its characteristics, and determine its orientation and target specifications according to the school's educational philosophy. Based on this 
education concept, universities need to cultivate students' creative work ability, creative thinking ability and creative problem-solving ability. Therefore, it is urgent to establish a practical talent training system.

\section{B. We will build a multi-level and all-covering education curriculum system for innovation and entrepreneurship}

First, the classroom is the "main battlefield" for cultivating students and the main channel for implementing education. Education course of innovation and entrepreneurship should be included in the compulsory course and corresponding credits should be given, and the organic combination of education and education should be insisted. According to their own teaching conditions and students' conditions, universities can divide the education course of innovation and entrepreneurship into education course system with multiple levels and full coverage. Colleges and universities should base on the regional development reality, according to the subject superiority and the research characteristic, forms has the local characteristic talented person training mode. In this way, innovation and entrepreneurship education can not only make full use of the favorable conditions of regional resources, but also provide high-quality talents for regional economic development.

Second, innovation and entrepreneurship education courses should be creative and characteristic. Colleges and universities should base on the regional development reality, according to the subject superiority and the research characteristic, forms has the local characteristic talented person training mode. In this way, innovation and entrepreneurship education can not only make full use of the favorable conditions of regional resources, but also provide high-quality talents for regional economic development.

Third, innovation and entrepreneurship education courses should be practical and instructive. Education course of innovation and entrepreneurship must be based on practice of education, so that students can obtain the theoretical methods, practical skills and communication skills necessary for daring to start a business and being able to innovate. Colleges and universities should give full play to the advantages of industryuniversity-research cooperation in educating people, actively encourage students to participate in teachers' research projects, and promote the cultivation of students' practical ability. At the same time, universities can also use teachers' research results as learning resources and case studies for students.

\section{WE WILL STRENGTHEN THE RANKS OF INNOVATIVE AND ENTREPRENEURIAL TEACHERS}

Teachers are the organizers and planners of the teaching process and one of the most important components of education system. In order to improve education level of innovation and entrepreneurship, colleges and universities need to build a team of innovative and entrepreneurial education teachers with excellent professional knowledge, strong practical ability, scientific research level and innovative spirit. Teachers are the backbone to complete talent training. Only when teachers keep improving their own quality and professional level can they do a good job in education teaching. Therefore, colleges and universities should make efforts to create conditions and carry out teacher training activities by "inviting in and going out". Cultivate the comprehensive quality of teachers' innovation and entrepreneurship.

\section{BUILD A PLATFORM FOR INNOVATION AND ENTREPRENEURSHIP}

At present, education practical teaching of innovation and entrepreneurship in China mainly has the following problems: insufficient policy support; the laboratory hours are seriously insufficient, and the laboratory is less open and sharing. Students benefit less from science and technology competitions There is a shortage of teachers. Therefore, education should highlight the practical teaching link, construct the practical teaching system scientifically and build the practical platform of innovation and entrepreneurship.

We will build a scientific and technological practice subplatform based on science and technology competitions and scientific research topics. As the famous education scholar Usenski once pointed out, "learning without any interest will kill students' desire to seek truth." Therefore, the model of student training should be followed: "school supervisor, teacher leading, student main body, all participation". The school can build a platform for science and technology practice, emphasizing the role of "transmitting, helping and guiding" senior students. Through academic exchanges and project development on the platform of science and technology practice, students' innovation ability and team spirit are cultivated. Students from different majors can communicate and cooperate with each other, with the goal of completing the same project, so as to achieve better interdisciplinary cooperation.

We will build a scientific and technological information exchange sub-platform based on a favorable environment. Colleges and universities should create a strong scientific and technological academic, innovative and entrepreneurial campus culture atmosphere, and actively play the role of the environment to educate people. The specific approach is :(1) make full use of network resources to provide information consulting services for undergraduates to innovate and start up education. (2) to build a unified network communication platform for students to disseminate scientific and technological trends, scientific and technological information and their own research results, as well as to seek help, find and release business opportunities through the network platform. (3) actively invite famous scholars, entrepreneurs, government officials and other successful people from both inside and outside the school to come to the school to give lectures, and conduct face-to-face communication with teachers and students through holding activities such as "famous scholar BBS", "lecture room", "alumni BBS" and "academic salon". In this way, teachers can broaden their horizons and improve their teaching ability. Secondly, students can broaden their horizons, enrich their knowledge and cultivate their innovative consciousness.

\section{CONCLUSION}

In a word, only by constructing the "practice-oriented" application-oriented personnel training system, constructing the 
"innovation and entrepreneurship" curriculum system, cultivating the "innovation and entrepreneurship" teachers, and constructing the "innovation and entrepreneurship" applicationoriented practical platform can we truly cultivate high-quality college application-oriented talents.

\section{REFERENCES}

[1] Zhang Xian-rui, XI Ting-ting. The practical path of education in college innovation and entrepreneurship training for application-oriented talents[J]. Heilongjiang higher education research.2015(1):147.

[2] CHEN Chun-lin. ZHU Zhang-qing. Education reform and practice of engineering discipline based on CDIO education concept[J]. Graduate education research,2010(1):30.
[3] GAO Cheng-hui, YANG Xiao-xiang. The research and practice of training high quality engineering science and technology talents in allround cooperation[J]. University teaching in China.2014(12).

[4] LI Tuo-yu, LI Fei, LU Guo-dong. An analysis on the way to improve the quality of engineering science and technology personnel training in "made in China 2025"[J]. Research on education in higher engineering.2015(6):17.

[5] LIU Bao-cun. The education concept of innovation and entrepreneurship was established, and the spirit of innovation and practical ability were cultivated[J]. China higher education.2010(12).

[6] XING Di-feng. Education path selection for innovation and entrepreneurship in higher vocational colleges. Heilongjiang higher education research.2011(04).

[7] ZENG Ai-ping. Some thoughts on the development of education schoolbased curriculum in higher vocational entrepreneurship[J]. China occupational technology education. 2011(18).

[8] ZHANG Jing,BAO Zong-ming. Discussion on the development of education course in higher vocational colleges[J]. Chinese adults education,2010(13). 